\title{
ТЕХНОЛОГІЯ ОРГАНІЗАЦІЇ ІННОВАЦІЙНОЇ ДІЯЛЬНОСТІ ЗАКЛАДІВ ДОШКІЛЬНОЇ ОСВІТИ
}

\author{
В статті розкривається технологія організації інноваційної діяльності закладів дошкільної освіти. \\ Представлено авторське трактування сутності технології реалізації інновацій, виділено ї̈ \\ характеристики: системність, діагностичність, результативність, стандартизація, \\ алгоритмічність, ефективність, керованість, відтворюваність, гнучкість. Визначено послідовність \\ і зміст етапів інновачійної діяльності: інформачійно-аналітичного, стратегічно-проектувального, \\ безпосередньої реалізаиії інновачій, їх активного використання та поширення.
}

Ключові слова: інновачія, інноващійний процес, інноваційна діяльність, інноваџійний заклад дошкільної освіти, інноваційна педагогічна система, технологія реалізації інновацій.

Постановка проблеми. Інноваційні процеси в сучасній дошкільній освіті спрямовані на створення та реалізацію ефективних концепцій, теорій, програм та методик розвитку й виховання дітей. Саме практика та якісно нові результати навчально-виховного процесу $є$ критерієм реальної актуальності й цінності нововведень. Однак, в закладах дошкільної освіти не завжди застосовуються продуктивні моделі й технології організації інноваційної діяльності. Інновації часто реалізуються фрагментарно, без належного науково-методологічного обгрунтування, чіткого прогнозування очікуваних результатів, планування послідовності етапів, необхідних ресурсів, часу, змісту робіт на кожному з них. Це призводить до втрати потенціалу нововведень. Метод проб і помилок у більшості випадків не дає бажаних результатів, а тільки спричинює марні витрати сил і зневіру педагогів в інноваціях. Успішність інноваційної діяльності закладу дошкільної освіти визначається не разовими, а постійними системними нововведеннями, що реалізуються 3 використанням технологій їх проектування, експертизи та моніторингу.

Аналіз останніх досліджень i публікацій. В контексті зазначеної проблеми значущими $\epsilon$ дослідження в галузі педагогічної інноватики з питань готовності закладів освіти до сприйняття та реалізації інновацій (А. І. Барановський, I. М. Дичківська, О. М. Коберник, В. С. Лазарєв, Н. В. Нечаєва, В. Ф. Паламарчук, М. М. Поташник, О. М. Саранов, І. Д. Фрумін, М. А. Ясвін та ін.), менеджменту інноваційної діяльності освітніх установ (Л. В. Вознюк, Л. М. Калініна, Т. М. Ковальова, Т. С. Перекрьостова， Н. С. Погрібна， Т. М. Сорочан， О. Г. Тринітатська та ін.). Вагомими також $є$ наукові розробки з теорії і технології проектування, експертизи та моніторингу інноваційної освітньої діяльності (Л. В. Буркова, В. П. Беспалько, О. Г. Важнова, В.В.Докучаєва, М. П. Горчакова-Сибірська, В. І. Загвязинський, Є. С. Заїр-Бек, І. Г. Срмаков, О. М. Коберник, І. О. Колеснікова, Г. М. Прозументова, Л. 3. Ребуха, В.В.Сєріков, Г. Д. Щекатунова, Д. Уілмс, В. З. Юсупов та ін.). Значна увага в дослідженнях приділяється аналізу особистісних характеристик суб’єктів інноваційної діяльності та формування інноваційного стилю мислення в педагогічному середовищі (К. Ангеловські, В. Л. Аношкіна, Г. І. Герасимов, В.П.Делія, Л. В. Ілюхіна, С. Міллер, С. В. Рєзванов, Поль А. Хебіг, С. Р. Янголовський та ін.). Відзначимо, що в сучасній зарубіжній інноватиці пріоритетними є пошуки технологічних способів реалізації та поширення інновацій у масовій практиці (А. Адамс, Х. Барнет, Е. Брансуіка, Н. Гросс, У. Кінгстон, Н. Лагервей, М. Майлз, А. Ніколлс, Е. Роджерс, Т. Хюсен та ін.). Аналіз досліджень свідчить, що ефективність інноваційної діяльності закладів дошкільної освіти пов'язана з використанням у процесі створення, відбору й реалізації інновацій спеціальних технологій, які недостатньо розробленні у вітчизняній педагогічній інноватиці.

Мета статті полягає в обгрунтуванні теоретичних засад та розробці процесуально-змістових етапів технології організації інноваційної діяльності закладів дошкільної освіти.

Виклад основного матеріалу. Педагогічні колективи закладів дошкільної освіти усвідомлюють, що в сучасних умовах стратегія інноваційного розвитку забезпечує їх конкурентоспроможність в наданні якісних освітніх послуг. Однак, труднощі, які виникають у керівників, методистів, вихователів при реалізації інновацій, актуалізують необхідність розробки та використання науково обгрунтованих та практично апробованих технологій організації інноваційної діяльності. Необхідність технологізації інноваційної діяльності обумовлена зростанням іiї складності за обсягами, кількістю суб'єктів, можливими ризиками, а також одночасним упровадженням різних нововведень. Реалізація окремих інновацій потребує значних затрат часових, людських, фінансових та інших ресурсів. А. В. Хуторський зазначає, що в сучасній системі освіти існує безліч моделей впровадження інновацій. Для кожної 
інновації часто пропонуються свій метод і своя стратегія. Це призводить до емпіризму та невдач у реалізації інновацій. Щоб вирішити цю проблему автор пропонує розробку методологічних основ та управлінських циклів проектування, цілепокладання, планування, програмування, організації системного моніторингу та корекції інноваційної діяльності [1].

Технологія досліджує й пропонує раціональні способи нововведень. Суттєвою ознакою технології $є$ те, що замість довільних, спонтанних дій вона пропонує чіткі алгоритмічні приписи, систему логічно послідовних етапів вирішення ієрархічної цілісності задач нововведення [2: 66]. Технологічно процес нововведень будується на принципах системності, цілеспрямованості, керованості на основі постійного моніторингу результатів, стандартизації, алгоритмічності, ефективності, відтворюваності, гнучкості й адаптивності.

Технологія реалізації інновацій - це науково обгрунтована модель й реальні дії втілення в життя стратегії інноваційного розвитку закладу дошкільної освіти. Основою технології є системний підхід до організації інноваційного процесу, який передбачає цілісність всіх його складових, ієрархічну послідовність етапів, виявлення і взаємодію зовнішніх і внутрішніх умов середовища, в якому реалізується інновація. А. І. Пригожин зазначає, що технологічні методи являються емпіричним втіленням системного підходу, з його ставкою на єдність цілого, планомірність, визначеність [3: 378]. У нашому тлумаченні технологія реалізації інновацій - це система, яка інтегрує інформацію про наявний стан педагогічної системи, в якій має впроваджуватися інновація, й передбачувані зміни в ній, які мають відбутися після реалізації інновації, а також сукупність оптимальних способів досягнення цих змін. У процесуально-змістовому аспекті технологія інноваційної діяльності закладу дошкільної освіти - це деталізовані форми, методи, прийоми, засоби вивчення, актуалізації та практичного загальнодоступного використання нововведень з урахуванням наявних умов і ресурсів.

Основне призначення технологічного підходу полягає у функціях систематизації, нормування, раціоналізації, оптимізації, регулювання, стабілізації, управління та саморозвитку процесу реалізації нововведень [4:38]. Зазначені функції вирішуються в задачах концептуального проектування інноваційної діяльності, чіткого прогнозування цілей і гарантованого досягнення іï результатів, визначення оптимального обсягу й послідовності дій та операцій, знаходження ефективних форм взаємодії суб'єктів нововведень, створення можливостей для зміни алгоритму дій, спрощення чи ускладнення операцій при зміні умов реалізації інновацій. Гнучкість технології забезпечується проектуванням основних етапів, алгоритмів діяльності та ключових обов'язкових точок контролю, між якими залишається простір для індивідуальної творчості педагогів.

Інноваційна педагогічна діяльність, виступаючи фактором розвитку освітніх систем, має такі особливості: грунтується на принципах особистісного підходу; має стійку вмотивованість на пошук нового в цільових, змістових і процесуальних характеристиках навчально-виховного процесу; носить творчий характер; організовується у формі дослідно-експериментальної роботи, що дозволяє не тільки по-різному будувати педагогічний процес, але і формувати нові моделі освітніх систем, в тому числі авторські [5: 4]. Інноваційна діяльність, на відміну від традиційної, характеризується високим рівнем невизначеності низки чинників, що впливають на їі результати. Прогностичний потенціал технології дозволяє передбачити потенційні ризики та труднощі й знизити можливі негативні відхилення від заданих параметрів в процесі впровадження нововведень.

Процесуально-технологічна складова технології організації інноваційної діяльності закладу дошкільної освіти конструюється як логічна черговість етапів з чіткою алгоритмізацією і деталізацією дій та операцій, які необхідно здійснити для вирішення аналітико-пошукових, організаційноуправлінських, проектувальних, методичних та інших задач у процесі реалізації інноваційних проектів. На основі узагальнення теоретичних підходів та практики нововведень нами визначено послідовність та зміст етапів технології організації інноваційної діяльності в закладах дошкільної освіти: 1) інформаційно-аналітичного - виявлення та аналіз проблем у функціонуванні та розвитку педагогічної системи та пошук можливих інноваційних способів їх вирішення; 2) стратегічно-проектувального вибір, концептуалізація та адаптація обраних інновацій до умов і потреб конкретного закладу дошкільної освіти; 3) безпосередньої реалізації інновацій - здійснення комплексу змін у структурі, функціях, pecypcax педагогічної системи, цінностях, мотивах, способах і результатах суб'єктів інноваційної діяльності; 4) активного використання та поширення інновації - розвитку інноваційного потенціалу закладу дошкільної освіти й одночасно подальшого розвитку самої інновації.

На інформаційно-аналітичному етапі 3 метою виявлення проблем та постановки задач подальшого розвитку проводиться моніторинг діяльності закладу дошкільної освіти, створюється та поповнюється база інновацій, упровадження яких може вирішити наявні протиріччя у функціонуванні педагогічної системи й стати джерелом їі розвитку. Обрані інновації проходять обов'язкову процедуру експертної оцінки за методологічним, процесуальним, ресурсним, технологічним критеріями, результати якої виступають основою для прийняття обгрунтованого рішення щодо доцільності та можливості їх реалізації у конкретному закладі освіти. Здійснюється оцінка 
інноваційного потенціалу закладу щодо достатності його ресурсів для реалізації певних інновацій. У ході такої підготовчої роботи в педагогічному колективі відбувається усвідомлення потреб та актуалізація мотивів інноваційних змін.

На стратегічно-проектувальному етапі педагогічний колектив визначається 3 інноваційною місією, концепцією та стратегією розвиту свого закладу. На цьому етапі важливо, щоб завдання та потенціал кожного інноваційного проекту узгоджувався із місією та загальною стратегією інноваційного розвитку закладу дошкільної освіти, його актуальними потребами в змінах та наявними ресурсами, які необхідні для якісної реалізації інновацій. Формування інноваційної стратегії розвитку навчального закладу передусім полягає в усвідомленні його місії - як бачення нових гуманістичних цінностей освіти, провідної ідеї, визначення образу свого майбутнього. Розробка місії $є$ відправною точкою удосконалення педагогічної системи дошкільного закладу й дозволяє визначити цінності його інноваційної освітньої діяльності для суспільства взагалі й конкретного оточення зокрема. Гуманістична спрямованість цінностей відображає унікальність закладу освіти, його імідж, з нею безпосередньо пов'язаний вибір освітньої моделі педагогами, батьками, усіма тими, хто здійснює цілеутворення й формує стратегію розвитку в навчальному закладі.

У кожному конкретному випадку визначення місії може відрізнятися, але дуже важливо, щоб вона вироблялася колегіально й стала результатом поєднання спільних цінностей і смислів діяльності. Тоді місія - як основна загальна мета, філософія, призначення, сенс діяльності інноваційного закладу освіти використовується в якості ціннісного орієнтиру для оцінки прийняття рішень, вибору нововведень, аналізу результатів діяльності.

Визначення місії має бути зрозумілим усім, щоб сприяти їх взаєморозумінню і співпраці при створенні та реалізації інноваційної стратегії діяльності навчального закладу. Стратегія - це довготерміновий, якісно вибраний напрям розвитку, який інтегрує місію, цілі організації, норми та дії в єдине ціле; визначає ресурсне забезпечення організації з урахуванням іiї внутрішніх переваг i недоліків, очікуваних змін і пов'язаних із ними дій конкурентів [6: 61]. Стратегія інноваційного розвитку навчального закладу - це довгострокове прогнозування майбутніх змін у педагогічній системі, розробка iï інноваційної моделі, яка визначає успішність переходу закладу дошкільної освіти з режиму функціонування в режим розвитку, який передбачає можливості швидко реагувати й своєчасно адаптуватися до запитів суспільства щодо оновлення цілей, змісту й якості освіти.

Традиційний заклад освіти стратегічно орієнтований на збереження стабільності, інноваційний заклад - на зміни в процесах управління, змісті й результатах розвитку та виховання дітей, стилю педагогічної взаємодії від прямого впливу до співробітництва й співтворчості й передбачає перегляд існуючих підходів, освоєння нових сфер і технологій діяльності. На відміну від інновації як процесу, який в основному проходить "за кулісами" й загалом не видимий споживачам, стратегічна інновація безпосередньо адресується суспільству у вигляді нових цінностей, цілей, що презентує унікальність, привабливість організації [7: 68]. Надзвичайно важливо, щоб місія й стратегічні цілі були прийняті й підтримувалися усім колективом.

Стратегічне планування як логіко-аналітичний процес здійснюється поетапно: 1) проводиться моніторинг нинішнього й можливого майбутнього стану зовнішнього й внутрішнього середовища закладу освіти; 2) визначаються основні соціальні та освітні орієнтири його діяльності; 3) на основі результатів першого й другого етапів визначаються можливі напрями розвитку, вибирається оптимальний варіант і формується власне стратегія; 4) розробляється план дій щодо реалізації стратегії, проводиться ії оцінка.

При плануванні інноваційної діяльності розробляється таксономія цілей нововведень, визначаються послідовність реалізації проектів, засоби інформаційно-методичного супроводу, способи управління, прогнозується необхідне кадрове, фінансове, матеріальне, просторо-часове забезпечення процесу реалізації інновацій.

На конструктивно-організаційному рівні планування формуються команди, творчі групи, конкретизуються завдання, розподіляються обов'язки, ролі, відповідальність, вибирається оптимальний режим і форми роботи, комунікації і взаємодії суб’єктів нововведень, забезпечуються засоби зворотного зв'язку для корекції діяльності.

На етапі безпосередньої реалізації інновацій відбувається комплекс змін у структурі, функціях, ресурсах, стилі мислення, способах діяльності й результатах, які вносять нововведення у практику роботи закладу освіти. Саме на цьому етапі повною мірою проявляється характерологічна особливість інновації як метадіяльності - діяльності зі зміни інших видів діяльності, спочатку особистісних структур іiї суб’єктів (потреб, мотивів, цілей, цінностей, смислів, установок), потім виконавчих структур (форм, методів, засобів) [8: 24].

Реалізація певної інновації окрім безпосередніх результатів, що визначаються іiї метою, спричинює низку супутніх змін в управлінні, методичній роботі, матеріально-технічних ресурсах, 
способах комунікації, підвищенні кваліфікації педагогів, логістиці потоків інформації тощо. Ці зміни суттєво підвищують інноваційний потенціал закладу освіти, що дозволяє освоєння більш складних, масштабних інновацій. Саме на цій стадії розкривається сутність інноваційної діяльності як цілеспрямованих змін педагогічної системи, що не лише вносять у їі структуру нові елементи, але й зумовлюють перехід системи з одного стану в інший.

Технологічні процедури цього етапу визначаються змістом і послідовністю дій, які необхідні для реалізації нововведення:

- вмотивоване цілесприйняття педагогами інновацій;

- перебудова особистісних структур і стилю мислення суб'єктів інноваційної діяльності;

- оптимізація інтелектуальних, технологічних, матеріально-фінансових, управлінських та інших ресурсів, необхідних для реалізації інновації;

- освоєння суб'єктами нововведень нових технологій інноваційної діяльності;

- адаптація нововведень до конкретних умов;

- зміни в структурі й функціях педагогічної системи;

- застосування нових моделей управління для координації дій всіх учасників нововведення;

- встановлення нових каналів зворотного зв’язку й налагодження моніторингу процесу реалізації інновації;

- коригування дій при відхиленні від прогнозованих параметрів нововведення;

- виявлення та оцінка нових результатів у роботі закладу освіти, контроль та підтримка їх якості, стійкості, ефективності;

- відстеження ефективності супутніх нововведень, які викликала реалізація основної інновації.

На етапі активного й продуктивного використання та поширення інновацій проявляються взаємопов'язані тенденції: інституалізації інновацій як джерела розвитку педагогічної системи закладу дошкільної освіти й одночасного подальшого вдосконалення самих інновацій.

Процесуально-змістовими компонентами технології інноваційної діяльності тут є:

- встановлення зв'язків нововведень 3 компонентами педагогічної системи, аналіз впливу інновацій на їх розвиток;

- оцінка змін в інноваційних ресурсах закладу освіти;

- рефлексія результатів й аналіз досвіду інноваційної діяльності, оцінка й відбір найбільш ефективних алгоритмів, схем, прийомів діяльності й включення їх в арсенал технології реалізації наступних нововведень;

- модифікація, удосконалення інновацій відповідно до нових цілей, умов, ресурсів і потреб розвитку закладу освіти;

- удосконалення технології інноваційної діяльності на основі набутого досвіду, виділення проблемних зон, оптимізації та раціоналізації дій, скорочення термінів їх виконання, одночасного паралельного виконання операцій, ліквідації непотрібних ланок;

- подальша реалізація модифікованих моделей інновацій як джерела сталого розвитку педагогічної системи;

- підтримка сприятливого соціально-психологічного клімату в колективі;

- прогнозування подальшого розвитку закладу та ініціювання наступних нововведень.

На етапах безпосередньої реалізації, активного використання та поширення інновації важливо, щоб у процесі моніторингових досліджень виявлялися не тільки причини проблем для їх усунення, а й чинники успіхів для їх підсилення та врахування в наступних проектах. Функціональне призначення моніторингу інноваційної діяльності визначається необхідністю контролю за дотриманням заданих концептуальних, змістовно-цільових і технологічних критеріїв та умов реалізації нововведення, оцінки його впливу на педагогічну систему i, в разі необхідності, коригування цього процесу. Постійний моніторинг забезпечує оперативне управління інноваційною діяльністю на основі постійного порівняння прогнозованих та фактично отриманих показників нововведення. В результаті аналізу й синтезу моніторингової інформації формується цілісне уявлення про хід реалізації інновацій, зміни в педагогічній системі, виявляються проблеми та уточнюються необхідні умови успішності інноваційної діяльності. Коригування - це оперативне внесення необхідних змін і доповнень у початковий варіант проекту реалізації інновацій у конкретних обставинах на основі зворотних зв’язків, які представляють складну систему причинно-наслідкових залежностей, що характеризують вплив результатів попередньої дії на подальший перебіг процесу [9: 29].

Ефект іррадіації (лат. irradiare - сяяти, випромінювати) притаманний не кожному нововведенню i спрацьовує не завжди. Чи буде інновація швидко втрачати свою новизну (рутинізація нововведення), чи буде модернізовуватися й значно відчутніше впливати на розвиток навчального закладу, залежить від його інноваційного потенціалу [2: 42]. Зміни в структурі, функціях, ресурсах педагогічної системи створюють можливості для вдосконалення інновацій, підвищення їх потенціалу у вирішенні актуальних задач закладу дошкільної освіти. I саме головне - в ході 
освоєння нововведень, осмислення набутих знань і досвіду, зростає рівень інноваційної компетентності педагогів і керівників начальних закладів, що уможливлює трансцендентне (таке, що не могло бути здійсненим спираючись на минулий чи наявний досвід) прогнозування нових цілей інноваційної діяльності. Здобутий досвід і більш високий рівень компетентності педагогів й ресурсів закладу дошкільної освіти дозволяє йому планувати й реалізовувати більш складні й масштабні системні інновації.

Загальні рекомендації, правові, організаційні, фінансові, кадрові та інші вимоги й процедури щодо впровадження інновацій на рівні окремого навчального закладу прописані у положенні Міністерства освіти і науки України "Про порядок здійснення інноваційної освітньої діяльності". Згідно з ним рівень інноваційної освітньої діяльності визначається ії змістом (розробка, розповсюдження чи застосування інновації), а також масштабністю змін, що вноситимуться у систему освіти внаслідок застосування запропонованої інновації [10].

Інноваційний заклад дошкільної освіти характеризується нами як відкрита соціально-педагогічна система, що постійно оновлює свої структуру й функції, оперативно реагує не тільки на наявні соціально-освітні детермінанти, а прогнозує можливі зміни суспільних потреб в освіті й на цій основі стратегічно планує розвиток своїх можливостей для випереджувального вирішення освітніх завдань у процесі суспільних трансформацій.

Проведений моніторинг матеріалів методичних кабінетів (центрів) управлінь освіти та ОІППО, в яких представлений досвід інноваційної діяльності закладів дошкільної освіти, дозволяє виділити такі їх типи: пасивні, репродуктивно-адаптивні, активно-адаптивні, системно-інноваційні.

Пасивні заклади дошкільної освіти не реагують на зміни й нововведення, впроваджують формально, лише за розпорядженням управлінь освіти. Репродуктивно-адаптивні заклади впроваджують педагогічні технології без урахування їх інноваційного потенціалу, аналізу своїх конкретних проблем, умов, в результаті чого зміни відбуваються тільки в окремих складових педагогічного процесу. Активно-адаптивні заклади прагнуть швидко реагувати на нові тенденції в освіті та педагогічній науці, але часто реалізують не узгоджені між собою окремі інноваційні проекти. Нерідко колективи таких закладів гоняться за значною кількістю різноманітних нововведень, що негативно впливає на їх якість та результативність, але вигідно для звітності та популярності. Заклади освіти системно-інноваційного типу організовують свою інноваційну діяльність на основі власної стратегії розвитку та місії, чіткого наукового обгрунтування концепції педагогічної системи. Колективи цих закладів проводять цілеспрямовану науково-експериментальну та методичну роботу, використовують різні форми підвищення кваліфікації, взаємодіють 3 науковими установами, закладами вищої освіти, створюють власну базу інновацій. Варто відзначити значне зростання за останні роки кількості закладів дошкільної освіти, що включаються в системну інноваційно-експериментальну діяльність. Ефективність їх інноваційної діяльності забезпечується застосуванням комплексу технологій менеджменту, проектування, експертизи, моніторингу, які спрямовані на уникнення стихійності й отримання прогнозованих результатів нововведень.

Висновки та перспективи подалышого дослідження проблеми. Інноваційна діяльність представляє собою послідовність етапів, організаційних процедур і засобів, за допомогою яких відбувається трансформація педагогічного відкриття або ідеї в реальні методики й технології практичної роботи вихователів закладів дошкільної освіти. Принциповим вихідним положенням у побудові технології організації інноваційної діяльності $\epsilon$ усвідомлення того, що інновація, як унікальний, вперше створений об'єкт, не може бути реалізована традиційними способами. Технологічний підхід уможливлює розробку нових продуктивних способів управління, проектування, контролю, відповідних умов, форм взаємодії учасників інноваційної діяльності, що в сукупності забезпечує їі ефективність та результативність.

Основним фактором, що забезпечує ефективність інноваційної діяльності закладу дошкільної освіти $є$ рівень відповідної компетентності педагогів, їх ціннісного ставлення до інновацій, сформованості інноваційного мислення, володіння технологіями експертизи, проектування моніторингу нововведень тощо. Тому перспективи подальших досліджень полягають в аналізі особистісних характеристик вихователів як суб’єктів інноваційної діяльності та вдосконалення форм і методів розвитку їх інноваційної компетентності.

\section{СПИСОК ВИКОРИСТАНИХ ДЖЕРЕЛ ТА ЛІТЕРАТУРИ}

1. Хуторской А. В. Теоретико-методологические основания инновационных процессов в образовании [Электронный ресурс] / А. В. Хуторской // Интернет-журнал "Эйдос". - 2005. - 26 марта. - Режим доступу : http://www.eidos.ru/journal/2005/0326.htm.

2. Дичківська І. М. Інноваційні педагогічні технології : [навч. посібник] / І. М. Дичківська. - К. : Академвидав, 2004. $-352 \mathrm{c}$.

3. Пригожин А. И. Методы развития организаций / А. И. Пригожин. - М. : МЦФЭР, 2003. - 863 с. 
4. Сурмин Ю. П. Теория социальных технологий : [учеб.пособ.] / Ю. П. Сурмин, Н. В. Туленков. - К. : МАУП, 2004. $-608 \mathrm{c}$.

5. Перекрестова Т. С. Становление и развитие авторской школы как инновационной образовательной системы : дис. ... канд. пед. наук : 13.00.01 / Татьяна Сергеевна Перекрестова. - Волгоград, 2001. - 252 с.

6. Освітній менеджмент в умовах змін : [навч. посіб.] / Л. Калініна, Л. Карамушка, Т. Сорочан [та ін.] / за ред. В. Олійника, Н. Протасової. - Луганськ : СПД Резніков В. С., 2011. - 308 с.

7. Такер Роберт Б. Инновации как формула роста : Новое будущее ведущих компаний / Роберт Б. Такер .- М. : Олимп-бизнес, 2006. - 224 с.

8. Карпова Ю. А. Инновации, интеллект, образование : [монографія] / Ю. А. Карпова. - М. : Изд-во МГУА, 1998. $-305 \mathrm{c}$.

9. Калініна Л. М. Інформаційне управління загальноосвітнім навчальним закладом: системи, процеси, технології : [монографія] / Л. М. Калініна.- К. : Інформавтодор, 2008. - 472 с.

10. Положення про порядок здійснення інноваційної освітньої діяльності [Електронний ресурс]. - Режим доступу : http://zakon4.rada.gov.ua/laws/ show/z0946-00.

\section{REFERENCES (TRANSLATED \& TRANSLITERATED)}

1. Khutorskoi A. V. Teoretiko-metodolohicheskie osnovaniia innovatsionnyh prozsessov v obrazovanii [Theoretically Methodological Bases of Innovative Processes in Education] [Elektronnyi resurs] / A. V. Khutorskoi // Internetzhurnal "Eidos" [Internet Magazine Eidos]. - 2005. - 26 marta. - Rezhym dostupu : http://www.eidos.ru/journal/2005/0326.htm.

2. Dychkivs'ka I. M. Innovatsiini pedagogichni tekhnologii [Innovational Pedagogical Technologies] : [navch. posib.] / I. M. Dychkivs'ka. - K. : Akademvydav, 2004. - 352 s.

3. Prigozhyn A. I. Metody razvitiia organizatzii [Methods of Organizations Development] / A. I. Prigozhyn. - M. : MTZFER, 2003. - $863 \mathrm{~s}$.

4. Surmyn Yu. P. Teoriia sotsyal'nykh tekhnolohii [Theory of Social Technologies] : [ucheb. posob.] / Yu. P. Surmyn, N. V. Tulenkov. - K. : MAUP, 2004. $-608 \mathrm{~s}$.

5. Perekrestova T. S. Stanovleniie i razvitie avtorskoi shkoly kak innovatsyonnoi obrazovatel'noi systemy [Forming and Development of Author's School as an Innovative System] : dys. ... kand. ped. nauk: 13.00.01 / Tatiana Serheevna Perekrestova. - Volhohrad, 2001. - 252 s.

6. Osvitnii menedzhment $\mathrm{v}$ umovakh zmin [Educational Management in Changing Conditions]: [navch. posib.]/ L. Kalinina, L. Karamushka, T. Sorochan [ta in.] / za red. V. Oliinyka, N. Protasovoi. - Luhansk: SPD Reznikov V. S., 2011. - 308 s.

7. Taker Robert B. Innovatsii kak formula rosta: Novoie budushchee vedushchykh kompanii [Innovations as a Formula of Growth : New Future of the Leading Companies] / Robert B. Taker . - M. : Olimp-biznes, 2006. - $224 \mathrm{~s}$.

8. Karpova Yu. A. Vvedenie v sotziologiiu innovatiki [Introduction into the Sociology of Innovation] : [uchebnoe posobie] / Yu. A. Karpova. - SPb. : Piter, 2004. - 192 s.

9. Kalinina L. M. Informatsiine upravlinnia zahalnoosvitnim navchal'nym zakladom : systemy, protsesy, tekhnolohii [Informational Control of a School: Systems, Processes, Technologies] : [monohrafiia] / L. M. Kalinina. - K. : Informavtodor, 2008. - $472 \mathrm{~s}$.

10. Polozhennia pro poriadok zdiisnennia innovatsiinoi osvitnioi diyal'nosti [The Statute on the Order of Innovative Educational Work Execution] [Elektronnyi resurs]. - Rezhym dostupu : http://zakon4.rada.gov.ua/laws/show/z094600 .

\section{Коновальчук И. И. Технология организации инновационной деятельности учреждений дошкольного} образования.

В статье раскрывается технология организации инновационной деятельности учреждений дошкольного образования. Представлены авторская трактовка сущности технологии реализаџии инновачий, выделены ее характеристики: системность, диагностичность, результативность, стандартизация, алгоритмичность, эффективность, управляемость, воспроизводимость, гибкость. Определена последовательность и содержание этапов инновационной деятельности: информационноаналитического, стратегически-проектировочного, непосредственной реализации инноваций, их активного использования и распространения.

Ключевые слова: инновация, инновационный процесс, инновационная деятельность, инновационный заведение дошкольного образования, инновационная педагогическая система, технология реализации инноваций.

\section{Konovalchuk I. I. Technology of Organization of Innovative Activities in Preschool Educational Institutions.}

In the article the theoretical basis and essential procedural steps to technological organization of innovative activities of preschool educational institutions are explained. Author's explanation to the notion "technology of realization of innovations" is presented, as a system that integrates information about current state of an object of innovation and intended changes in it, that have to appear after the innovation happens, also the variety of ways that provide optimal way to achieve these changes. 
The subject of technology of providing innovations is specified - finding logical sequence and development of complex forms, methods, means of introduction of innovations into pedagogical system of a preschool educational institution and the mechanisms of their productive and affordable use.

Common trades of technological process are specified: system orientation, diagnostics, result, standardizing, algorithm, effectiveness, control, quality of being able to repeat, flexibility and ability to adapt. The sequence and essence of stages of introducing the innovation are developed: informative and analytic-detection and analysis of the problems in functioning of a preschool educational institution and possible innovative ways to solve them; strategically-projective - choice, conceptualization and adaptation of innovation to the conditions and needs of certain preschool educational institution; introduction of the very innovation itself-creation of complex changes in the structure, functions, resources of pedagogical system, values, motifs, ways of action of certain objects of innovation and results, that an innovation adds into practice of educational institution, active and productive use of innovation - development of pedagogical system and simultaneously further development of innovation.

The essence of innovative preschool educational institution is characterized as an opened social pedagogical system that quickly reacts to social and educational determinants of changes of social needs in education and constantly renovates its structure and functions. Based on an empirical research, depending on content and results of innovative activity the passive, reproductive adaptive, active adaptive, system innovative types of preschool educational institutions are outlined.

Key words: innovation, innovative process, innovative activity, innovative preschool educational institution, innovative pedagogical system, technology of introduction of innovations. 